Vol.7, No. 1, 2021, 21-33

ISSN: 2053-2369 (print version), 2053-2377 (online)

https://doi.org/10.47260/johphn/712

Scientific Press International Limited

\title{
Burnout Syndrome and Anxiety/Depressive Disorders in Healthcare Professionals: A Canonical Correlation Analysis
}

\author{
S. Giakoumatos ${ }^{1}$, D. Nikolakopoulos ${ }^{2}$ and A. Athanasopoulos ${ }^{3}$
}

\begin{abstract}
In this research, the burnout syndrome and the anxiety/depressive disorder are combined studied in the healthcare professionals. Our target is to examine the association in the two measurements. We provide statistical analysis in order to determine the statistically significant independent variables that affect the two medical conditions and then we applied canonical correlation analysis (CCA) in order to reveal the correlation between the different dimensions/factors of the two measurements.
\end{abstract}

Key words: Burnout, Anxiety, Canonical correlation.

\footnotetext{
1 University of Peloponnese, Greece.

${ }^{2}$ University of Peloponnese, Greece.

${ }^{3}$ University of Peloponnese, Greece.
}

Article Info: Received: May 10, 2021. Revised: May 20, 2021.

Published online: June 21, 2021. 


\section{Introduction}

According to World Health Organization, health is "a state of complete physical, mental and social well-being, not just the absence of disease or disability", while mental health is defined as "... a state of well-being in which the individual realizes his potential, is able to cope with the usual stresses of life, can work productively and efficiently and is able to contribute to his social environment". Work is also an integral part of a full life. In recent years, however, professional burnout has been the focus of research interest due to the particularly negative effects it has on the individual's personal life as well as on his physical and mental health.

At the same time, research has shown a strong association between burnout and anxiety/depression. Burnout and depression are two separate concepts, but they have some common features, especially in severe forms of exhaustion. The aim of the present study is to investigate the relationship of anxiety and depressive disorders with burnout in health professionals.

Health care is a working environment with intense physical and psychological burden due to the exhausting hours and the daily contact with the patient's pain. Therefore, it is of paramount importance to highlight the risk factors that psychologically burden the employee of health care, in order to reduce the risk of anxiety, depression and burnout syndrome.

\section{Work anxiety}

The intensification of work, the constant changes, the growing demands both in personal and professional life are some of the factors that create stressful situations for employees. When the pressure exceeds the individual's ability to cope with it and to cope with the demands, then the work anxiety appears (Vakola \& Nikolaou, 2012). Therefore, work anxiety is the harmful physical and emotional reaction that people experience at work, as a result of the accumulation of work-related stressors (Greenberg \& Baron, 2013). The work environment causes stress to the employee when demands are high, the possibility of choice and participation in decision making is limited and social relationships in the workplace are bad. In addition, work causes stress to the employee when it is monotonous and does not help him develop or utilize his/her inclinations or acquire new knowledge and skills. (Cantas, 1998).

\section{Burnout syndrome}

One of the most widely accepted definitions of burnout was given by Maslach, who described a syndrome of physical and mental exhaustion, in which the employee loses his/her interest and positive feelings he had for his patients, ceases to be satisfied with his work and performance and develops negative image of himself. According to Maslach \& Jackson (1986), the three main factors that distinguish burnout are: 
- Emotional exhaustion, manifested by a feeling of mental fatigue of the professional who has no longer the energy to invest in his work.

- Depersonalization, which manifests with the development of impersonal relationships with patients.

- Lack of personal achievement, manifested by the reduction of his/her performance and his resignation from any attempt to effectively deal with the problems of patients and to chase personal development.

Burnout does not appear suddenly and it is not result of an individual stressful event. It is a multifactorial phenomenon and is considered the result of chronic, accumulated stress that overwhelms the professional and makes him feel that his mental stocks are not sufficient to withstand the pressure of the workplace. According to Edelwich \& Brodsky (1980), burnout develops through four successive stages:

1. In the first stage, that of enthusiasm, the professional enters the field of health having too high goals and unrealistic expectations from himself, from the patients, his/her colleagues and working conditions.

2. In the second stage, which includes doubt and inaction, the professional begins to realize that his work does not meet his expectations and deepest needs and tries to cover his/her frustration with harder and more intensive work. The professional is annoyed that his offer does not recognized, complains about the low salary, the exhausting hours, lack of support and more.

3. In the third stage, that of frustration, the professional wonders if it is worth doing a job that creates stress and from which he does not derive the satisfaction he expected. He perceives reality as a dead end, he/she reconsiders the unrealistic goals and expectations and modifies his/her behavior, so as to move away from patients and the workplace that cause intense stress.

4. In the fourth stage of apathy, the professional invests minimal energy in his work, ignores the needs of his patients as he feels inadequate to meet them, avoids responsibilities, changes or innovations in the workplace and maintains his position only for financial reasons.

According to the existing research background, there is a strong correlation between burnout and symptoms of anxiety and depression. The factors that contribute to the burnout of health professionals are: lack of staff, excessive workload, continuing working hours, daily exposure to pain and death of patients, increased demands, conflicts with patients and their relatives, ambiguity of roles and responsibilities and limited sense of power. Exhausted health workers also show indifference towards patients as well as inability to respond to their work demands. Research is divided concerning the relationship between age and burnout: younger age is associated with either more stress resistance or less experience and more work stress. Moreover, family can either act protectively by reducing the risk of burnout or contribute to the burnout due to the difficulty of balancing family and work life. 
Women tend to show symptoms of anxiety, depression and exhaustion at a higher frequency than men. Last but not least, a higher level of education can provide the skills and knowledge to cope with burnout or can be associated with positions of higher responsibility and contribute to stress and burnout (Dilintas, 2010, Mpaltzi et al., 2012, Gregoropoulou et al., 2018, Tsilias et al., 2014, Karaniadou, Anagnostopoulos \& Telioni, 2006, Roupa et al., 2008, Alexias, Anagnostopoulos \& Pilatis, 2010, Douvanas et al., 2011, Vlachou, et al., 2016, Antoniou, Davidson \& Cooper, 2006, Kaklamanou et al., 2014, Tsetseli \& Trigoni, 2017, Kiloudis et al., 2011, Moustaka et al., 2010, Tsaras et al., 2018)

The aim of this study was to investigate the relationship between burnout and anxiety-depressive disorders in health professionals. The research questions were the following:

- Are higher levels of burnout associated with higher levels of stress and depression?

- What is the relationship between gender, age, marital status, number of children, educational background, years of employment with burnout, stress and depression?

\section{Methodology}

The research was conducted in health professionals of Patras University Hospital with random sampling. The two scales used were:

- The Depression-Anxiety-Stress Scale (DASS-42), a self-reporting scale with 3 subscales (depression, anxiety, stress), which has been translated and weighted in greek population.

- The Copenhagen Burnout Inventory (CBI), which includes 3 subscales (personal burnout, burnout related to work, burnout related to patients).

Initially, descriptive statistics of the demographic characteristics and the frequencies of burnout and anxiety-depressive disorders were extracted. Then, t-test and ANOVA test were performed to find the relationship between demographics and both scales (anxiety-depressive disorders and burnout). Finally, Canonical Correlation Analysis (CCA) was performed to detect the relationship between the 6 subscales (anxiety, stress, depression, personal burnout, work-related burnout, patient burnout). The innovation of the present work lies in the application of the CCA to determine the relationship between burnout and depression. CCA is a suitable technique when there is a need to analyze the relationship between two sets of variables. 


\section{Results}

101 health professionals participated in the present study, of which 78,2\% were women. The mean age of the participants was 45.8 years, while the sample included 68 married $(67.3 \%)$ participants and $68.3 \%$ of the participants had children. $41.6 \%$ were graduates of higher education and the mean years of service were 22.5 years. The detailed socio-demographic characteristics of the sample are shown in Table 1.

Table 1: Socio-demographic characteristics

\begin{tabular}{|c|c|c|c|c|}
\hline \multicolumn{5}{|c|}{ SEX } \\
\hline \multicolumn{2}{|c|}{$\begin{array}{c}\text { Men } \\
22(21,8 \%)\end{array}$} & \multicolumn{3}{|c|}{$\begin{array}{c}\text { Women } \\
79(78,2 \%)\end{array}$} \\
\hline \multicolumn{5}{|c|}{ FAMILY STATUS } \\
\hline $\begin{array}{c}\text { Married } \\
68(67,3 \%)\end{array}$ & $\begin{array}{c}\text { Single } \\
26(25,7 \%)\end{array}$ & \multicolumn{3}{|c|}{$\begin{array}{l}\text { Divorced } \\
7(6,9 \%)\end{array}$} \\
\hline \multicolumn{5}{|c|}{ CHILDREN } \\
\hline \multicolumn{2}{|c|}{$\begin{array}{c}\text { Yes } \\
69(68,3 \%)\end{array}$} & \multicolumn{3}{|c|}{$\begin{array}{c}\text { No } \\
32(31,7 \%)\end{array}$} \\
\hline \multicolumn{5}{|c|}{ NUMBER OF CHILDREN } \\
\hline \multicolumn{2}{|c|}{$\begin{array}{c}0 \\
32(31,7 \%)\end{array}$} & $\begin{array}{c}1 \\
17(16,8 \%)\end{array}$ & $\begin{array}{c}2 \\
33(32,7 \%)\end{array}$ & $\begin{array}{c}3 \\
15(14,9 \%)\end{array}$ \\
\hline \multicolumn{5}{|c|}{ EDUCATIONAL LEVEL } \\
\hline Compuls & ucation & $\begin{array}{c}\text { Secondary } \\
\text { education } \\
40(39,6 \%)\end{array}$ & $\begin{array}{c}\text { Higher } \\
\text { education } \\
42(41,6 \%)\end{array}$ & $\begin{array}{c}\text { Master } \\
17(16,8 \%)\end{array}$ \\
\hline \multicolumn{5}{|c|}{ AGE } \\
\hline \multicolumn{2}{|c|}{$\begin{array}{c}\text { Minimum } \\
20\end{array}$} & $\begin{array}{c}\text { Maximum } \\
58\end{array}$ & \multicolumn{2}{|c|}{$\begin{array}{c}\text { Mean } \\
45,8\end{array}$} \\
\hline \multicolumn{5}{|c|}{ YEARS OF SERVICE } \\
\hline \multicolumn{2}{|c|}{$\begin{array}{c}\text { Minimum } \\
1 \\
\end{array}$} & $\begin{array}{c}\text { Maximum } \\
35\end{array}$ & \multicolumn{2}{|c|}{$\begin{array}{c}\text { Mean } \\
22,5\end{array}$} \\
\hline \multicolumn{5}{|c|}{ POSITION } \\
\hline \multicolumn{3}{|c|}{$\begin{array}{c}\text { Nurses } \\
88(87,1 \%)\end{array}$} & \multicolumn{2}{|c|}{$\begin{array}{c}\text { Doctors } \\
13(12,9)\end{array}$} \\
\hline
\end{tabular}

The averages of the subscales of stress, anxiety and depression were 17.3, 18.3, 15.3 respectively and indicated that the participants experienced severe stress, mild anxiety and moderate depression. Furthermore, the averages of the subscales of personal burnout, work-related burnout and patient-related burnout were 15.6, 19.8, 14.2 respectively. Work-related burnout and personal burnout were high, in contrast to the lower scores of patient-related burnout.

Regarding the relationship between anxiety, stress and depression with the general 
characteristics of the participants (Tables 2, 3, 4, 5):

- Women were more likely to experience stress than men (p-value of ttest $=0.042<0.05$ ). No statistically significant difference was found between men and women in terms of anxiety and depression.

- Singles tended to have lower scores of stress ( $\mathrm{p}$-value of $\mathrm{t}$-test $=0.001<0.05)$, anxiety ( $\mathrm{p}$-value of $\mathrm{t}$-test $=0.001<0.05)$ and depression $(\mathrm{p}$-value of $\mathrm{t}$ test $=0.022<0.05)$ compared to married people.

- Having children was associated with higher levels of stress (p-value of ttest $=0.001<0.05)$, anxiety ( $\mathrm{p}$-value of $\mathrm{t}$-test $=0.001<0.05)$ and depression $(\mathrm{p}-$ value of $\mathrm{t}$-test $=0.020<0.05)$.

- Higher education was associated with lower levels of anxiety (p-value of ttest $=0.000<0.05)$, stress ( $\mathrm{p}$-value of $\mathrm{t}$-test $=0.000<0.05)$ and depression $(\mathrm{p}$ value of $\mathrm{t}$-test $=0.001<0.05)$.

Regarding the relationship between burnout and the general characteristics of the participants (Tables 2, 3, 4, 5):

- Women were more likely to experience personal burnout ( $\mathrm{p}$-value of $\mathrm{t}$-test $=0.001<0.05$ ), work-related burnout ( $\mathrm{p}$-value of $\mathrm{t}$ test $=0.003<0.05)$ and patient-related burnout $(\mathrm{p}$-value of $\mathrm{t}$-test $=0.042<0.009)$ than men.

- Singles tended to have lower scores of personal burnout ( $\mathrm{p}$-value of $\mathrm{t}$-test $=0.001<0.05)$, work-related burnout ( $\mathrm{p}$-value of $\mathrm{t}$ test $=0.001<0.05)$ and patient-related burnout $(\mathrm{p}$-value of $\mathrm{t}$-test $=0.001<0.05)$ compared to married people.

- Having children was associated with higher levels of personal burnout (pvalue of $\mathrm{t}$-test $=0.000<0.05$ ), work-related burnout ( $\mathrm{p}$-value of $\mathrm{t}$ test $=0.000<0.05)$ and patient-related burnout ( $\mathrm{p}$-value of $\mathrm{t}$-test $=0.000<0.05)$.

- Higher educational level was associated with lower levels of personal burnout ( $\mathrm{p}$-value of $\mathrm{t}$-test $=0.000<0.05$ ), work-related burnout $(\mathrm{p}$-value of $\mathrm{t}$-test $=0.000<0.05)$ and patient-related burnout $(\mathrm{p}$-value of $\mathrm{t}$ test $=0.000<0.05)$. 
Table 2: Sex, DASS and CBI scores

\begin{tabular}{|c|c|c|c|c|c|c|}
\hline & & $\mathbf{N}$ & Mean & $\begin{array}{c}\text { Std. } \\
\text { Deviation }\end{array}$ & $\begin{array}{c}\text { Std. Error } \\
\text { Mean }\end{array}$ & $\begin{array}{l}\text { P-Value } \\
\text { of t-test }\end{array}$ \\
\hline \multirow{2}{*}{$\begin{array}{l}\text { STRESS } \\
\text { SCORE }\end{array}$} & MEN & 22 & 14,4091 & 10,25234 & 2,18581 & \multirow{2}{*}{,042 } \\
\hline & WOMEN & 79 & 18,0506 & 6,29998 & ,70880 & \\
\hline \multirow{2}{*}{$\begin{array}{c}\text { ANXIETY } \\
\text { SCORE }\end{array}$} & MEN & 22 & 15,8182 & 9,51008 & 2,02756 & \multirow{2}{*}{,077 } \\
\hline & WOMEN & 79 & 18,9367 & 6,50708 & ,73210 & \\
\hline \multirow{2}{*}{$\begin{array}{l}\text { DEPRESSION } \\
\text { SCORE }\end{array}$} & MEN & 22 & 13,5455 & 9,35403 & 1,99429 & \multirow{2}{*}{,316 } \\
\hline & WOMEN & 79 & 15,7342 & 7,04147 & ,79223 & \\
\hline \multirow{2}{*}{$\begin{array}{c}\text { PERS. } \\
\text { BURNOUT }\end{array}$} & MEN & 22 & 15,2273 & 8,43988 & 1,79939 & \multirow{2}{*}{,001 } \\
\hline & WOMEN & 79 & 20,8734 & 5,97724 & 67249 & \\
\hline \multirow{2}{*}{$\begin{array}{c}\text { WORK } \\
\text { BURNOUT }\end{array}$} & MEN & 22 & 16,0455 & 8,12097 & 1,73140 & \multirow{2}{*}{,003 } \\
\hline & WOMEN & 79 & 20,8734 & 6,11716 & ,68823 & \\
\hline \multirow{2}{*}{$\begin{array}{l}\text { PATIENT } \\
\text { BURNOUT }\end{array}$} & MEN & 22 & 12,5000 & 8,95358 & 1,90891 & \multirow{2}{*}{,009 } \\
\hline & WOMEN & 79 & 17,2532 & 6,86214 & ,77205 & \\
\hline
\end{tabular}

Table 3: Family status, DASS and CBI scores

\begin{tabular}{|c|c|c|c|c|c|c|}
\hline & & $\mathbf{N}$ & Mean & $\begin{array}{c}\text { Std. } \\
\text { Deviation }\end{array}$ & $\begin{array}{c}\text { Std. Error } \\
\text { Mean }\end{array}$ & $\begin{array}{l}\text { P-Value } \\
\text { of t-test }\end{array}$ \\
\hline \multirow{2}{*}{$\begin{array}{l}\text { STRESS } \\
\text { SCORE }\end{array}$} & MARRIED & 68 & 18,3529 & 6,55576 &, 79500 & \multirow{2}{*}{, 001} \\
\hline & SINGLE & 26 & 12,8846 & 7,09550 & 1,39154 & \\
\hline \multirow{2}{*}{$\begin{array}{l}\text { ANXIETY } \\
\text { SCORE }\end{array}$} & MARRIED & 68 & 19,5147 & 6,69705 & ,81214 & \multirow{2}{*}{, 001} \\
\hline & SINGLE & 26 & 13,9231 & 6,49260 & 1,27330 & \\
\hline \multirow{2}{*}{$\begin{array}{l}\text { DEPRESSI } \\
\text { ON SCORE }\end{array}$} & MARRIED & 68 & 16,0588 & 6,88256 & ,83463 & \multirow{2}{*}{,022 } \\
\hline & SINGLE & 26 & 12,0000 & 7,58419 & 1,48738 & \\
\hline \multirow{2}{*}{$\begin{array}{c}\text { PERS. } \\
\text { BURNOUT }\end{array}$} & MARRIED & 68 & 20,8824 & 6,05332 & ,73407 & \multirow{2}{*}{,001 } \\
\hline & SINGLE & 26 & 15,4615 & 7,69535 & 1,50918 & \\
\hline \multirow{2}{*}{$\begin{array}{c}\text { WORK } \\
\text { BURNOUT }\end{array}$} & MARRIED & 68 & 21,0588 & 6,06650 & ,73567 & \multirow{2}{*}{,001 } \\
\hline & SINGLE & 26 & 15,7692 & 7,58054 & 1,48667 & \\
\hline \multirow{2}{*}{$\begin{array}{l}\text { PATIENT } \\
\text { BURNOUT }\end{array}$} & MARRIED & 68 & 17,5000 & 6,77022 & ,82101 & \multirow{2}{*}{,001 } \\
\hline & SINGLE & 26 & 11,8077 & 8,31394 & 1,63050 & \\
\hline
\end{tabular}


Table 4: Having children, DASS and CBI scores

\begin{tabular}{|c|c|c|c|c|c|c|}
\hline & & $\mathbf{N}$ & Mean & $\begin{array}{c}\text { Std. } \\
\text { Deviation }\end{array}$ & $\begin{array}{l}\text { Std. Error } \\
\text { Mean }\end{array}$ & $\begin{array}{l}\text { P-Value } \\
\text { of t-test }\end{array}$ \\
\hline \multirow{2}{*}{$\begin{array}{l}\text { STRESS } \\
\text { SCORE }\end{array}$} & YES & 69 & 19,0580 & 6,68159 &, 80437 & \multirow{2}{*}{,001 } \\
\hline & $\mathrm{NO}$ & 32 & 13,3750 & 7,59775 & 1,34311 & \\
\hline \multirow{2}{*}{$\begin{array}{l}\text { ANXIETY } \\
\text { SCORE }\end{array}$} & YES & 69 & 20,0145 & 6,67412 & ,80347 & \multirow{2}{*}{,001 } \\
\hline & NO & 32 & 14,4688 & 7,33522 & 1,29670 & \\
\hline \multirow{2}{*}{$\begin{array}{l}\text { DEPRESSION } \\
\text { SCORE }\end{array}$} & YES & 69 & 16,5217 & 7,09517 &, 85416 & \multirow{2}{*}{,020 } \\
\hline & $\mathrm{NO}$ & 32 & 12,5313 & 8,06420 & 1,42556 & \\
\hline \multirow{2}{*}{$\begin{array}{c}\text { PERS. } \\
\text { BURNOUT }\end{array}$} & YES & 69 & 21,6377 & 5,78276 & ,69616 & \multirow{2}{*}{,000 } \\
\hline & NO & 32 & 15,3438 & 7,38617 & 1,30570 & \\
\hline \multirow{2}{*}{$\begin{array}{c}\text { WORK } \\
\text { BURNOUT }\end{array}$} & YES & 69 & 21,7391 & 5,68707 & ,68464 & \multirow{2}{*}{,000 } \\
\hline & $\mathrm{NO}$ & 32 & 15,6875 & 7,41593 & 1,31096 & \\
\hline \multirow{2}{*}{$\begin{array}{l}\text { PATIENT } \\
\text { BURNOUT }\end{array}$} & YES & 69 & 18,3623 & 6,25904 & ,75350 & \multirow{2}{*}{,000 } \\
\hline & NO & 32 & 11,5938 & 8,19071 & 1,44793 & \\
\hline
\end{tabular}

Table 5: Educational level, DASS and CBI scores

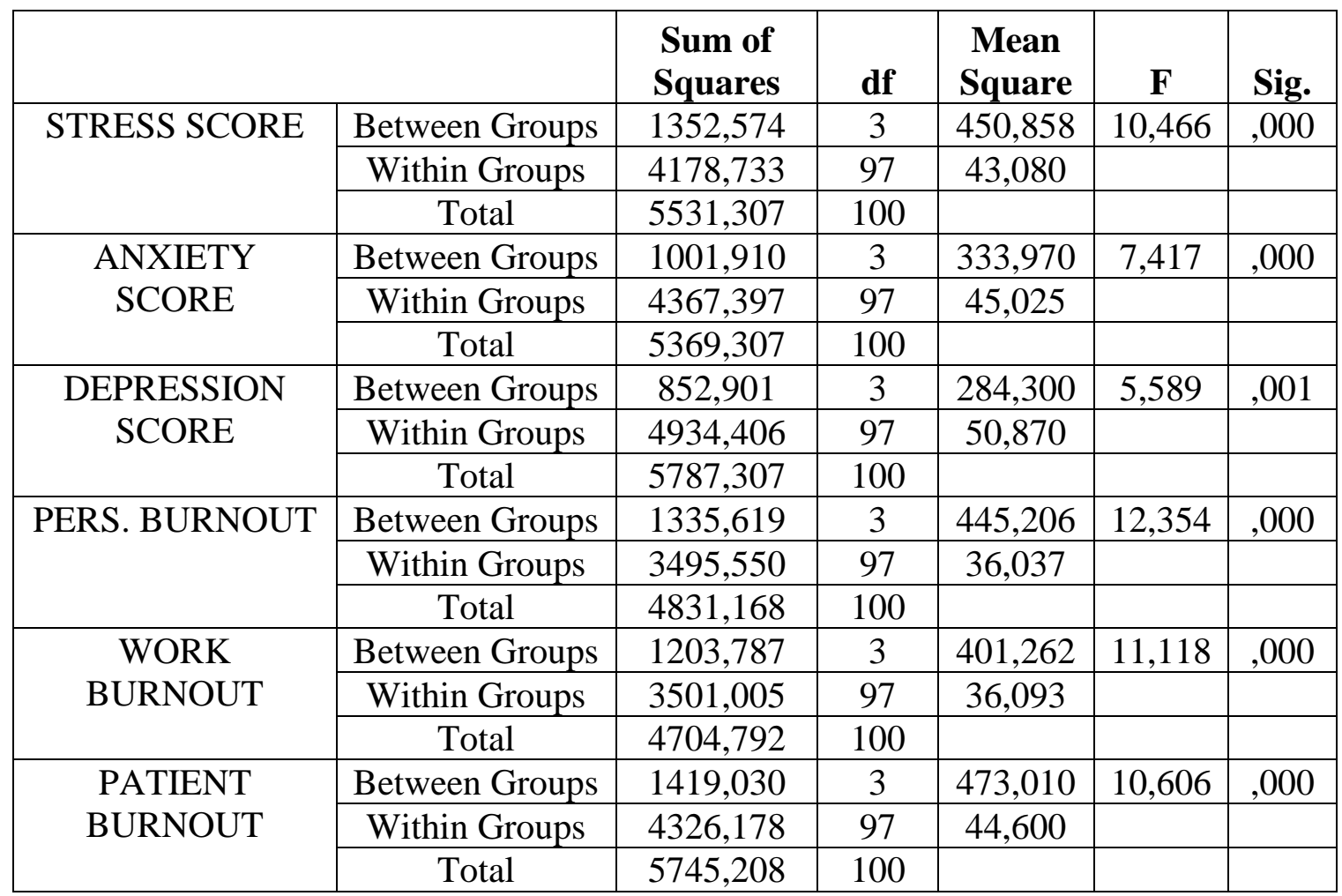


Older age was associated with higher scores of anxiety, stress and depression. In addition, older age was associated with higher burnout scores. The number of children was positively associated not only with higher scores of stress, anxiety, depression but also with higher scores of burnout. More years of employment were associated with higher scores of stress, anxiety, depression as well as higher burnout scores (Table 6).

Table 6: Age, number of children, years of employment, DASS and CBI scores

\begin{tabular}{|l|c|c|c|}
\hline & AGE & $\begin{array}{c}\text { NUMBER OF } \\
\text { CHILDREN }\end{array}$ & $\begin{array}{c}\text { YEARS OF } \\
\text { EMPLOYMENT }\end{array}$ \\
\hline STRESS SCORE &, 658 &, 322 &, 311 \\
\hline ANXIETY SCORE &, 785 &, 419 &, 397 \\
\hline DEPRESSION SCORE &, 675 &, 241 &, 243 \\
\hline PERS. BURNOUT &, 363 &, 291 &, 149 \\
\hline WORK BURNOUT &, 243 &, 660 &, 163 \\
\hline PATIENT BURNOUT &, 172 &, 256 &, 241 \\
\hline
\end{tabular}

A key finding of the three CCA models is the positive correlation between anxiety /depressive disorders and burnout. The strongest correlation between the two variables is derived from the first analysis. However, in each model resulting from the corresponding analysis we observe that the factors that better explain the variation and therefore the overall model differ. The 1 st model can be interpreted as: Health professionals with higher stress and anxiety scores tend to score higher on personal and patient-related burnout or vice versa. In addition, the weighs and negative signs of depression and work-related burnout are attributed to the fact that the model is better explained by the influence of the other subfactors. In the second and the third model the correlation of the two main variables remains positive but becomes weaker. Another important finding of the three models is that the factors that seem to have the most significant effect on the variable $X$ are anxiety and stress, while the corresponding factor for the variable $\mathrm{H}$ is personal burnout (Figures 1,2,3). 


\section{Conclusions}

Significant rates of anxiety-depressive disorders and burnout were detected in the sample. A strong correlation exists between anxiety/depressive disorders and burnout syndrome. Women and older employees are significant risk groups and require special prevention measures. The combination of work and family tasks seems to create intense stress to health professionals, a key finding showed by as well.

Higher educational level is associated with greater resilience to work challenges and more effective management of increased pressure and responsibilities. As a conclusion. healthcare is a working environment with intense physical and psychological burden due to the exhausting hours and the daily contact with the patient's pain. Early prevention of burnout of health professionals is of paramount importance, as the effective functioning of the health system as well as the life and healing of thousands of patients depend on them. Undoubtedly, the existence of health professionals with low levels of burnout and a positive emotional attitude in the daily working routine is the cornerstone of the healthcare effectiveness and quality. 


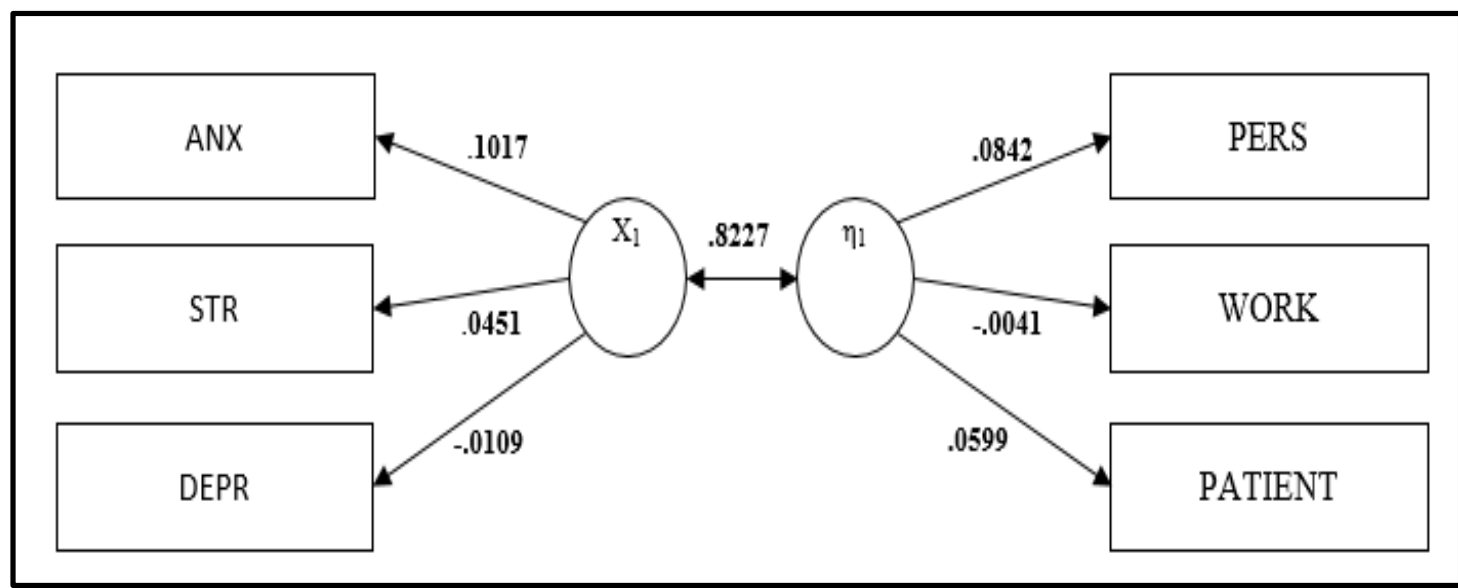

Figure 1: $1^{\text {st }}$ CCA model

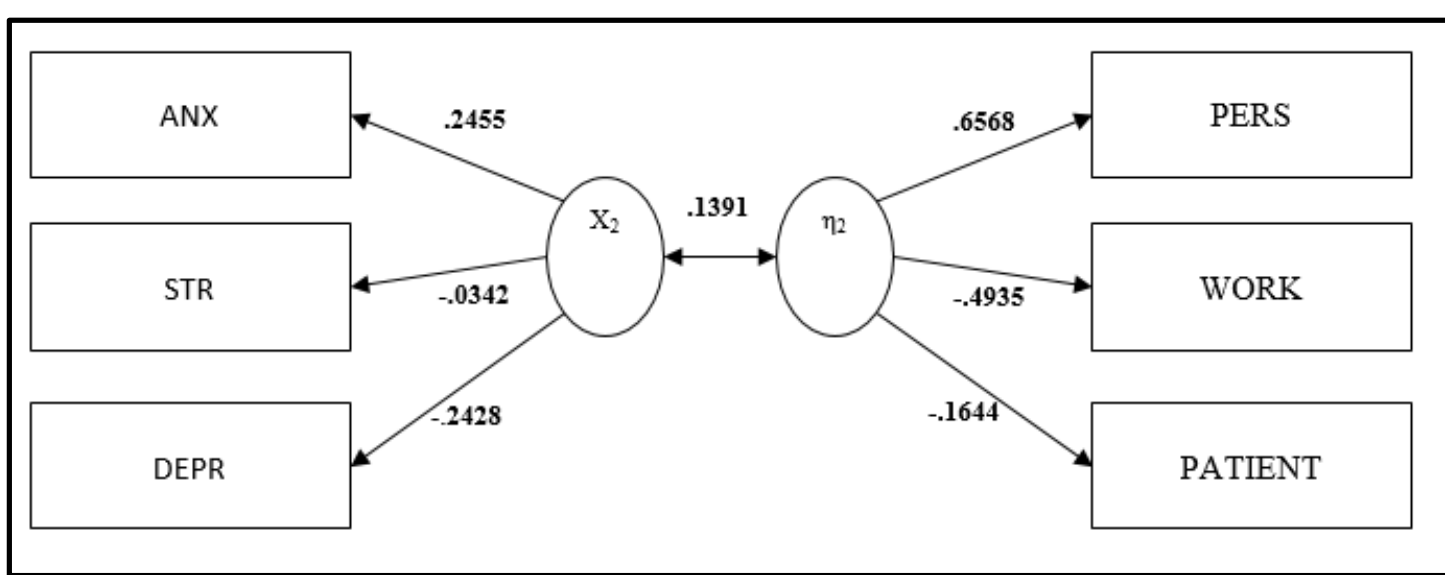

Figure 2: $2^{\text {nd }}$ CCA model

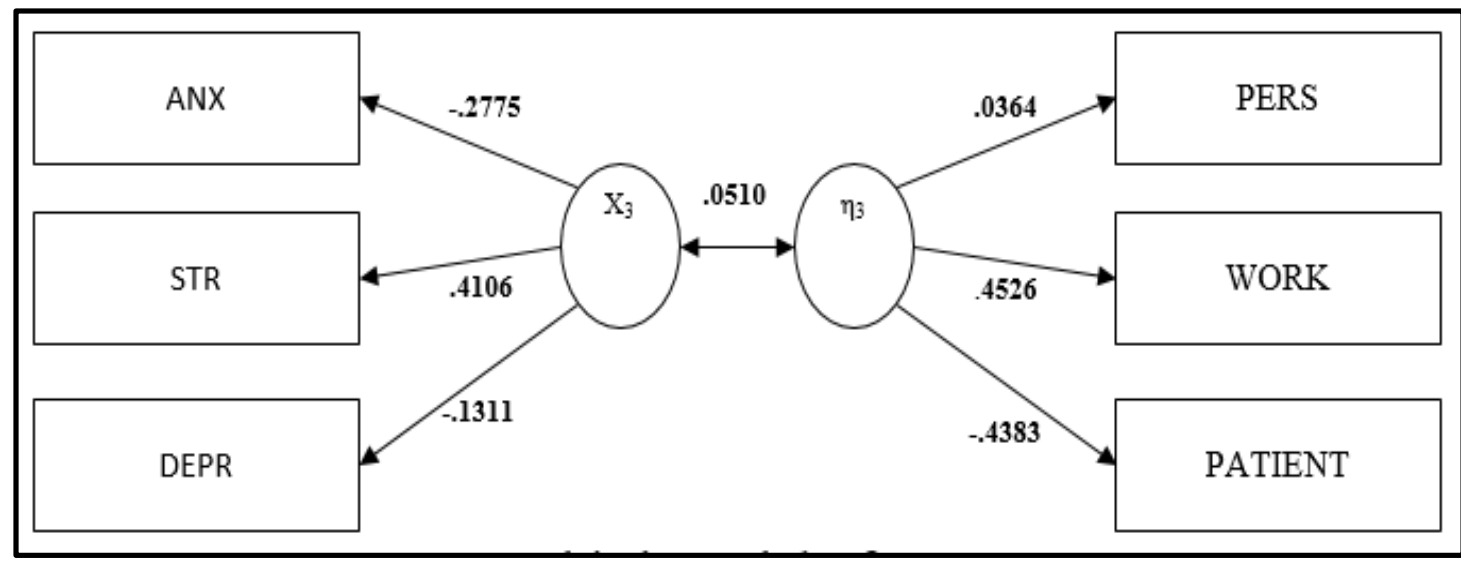

Figure 3: 3d CCA model 


\section{References}

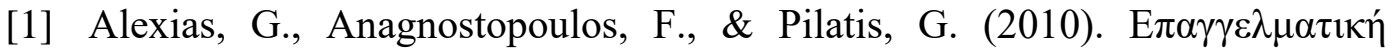

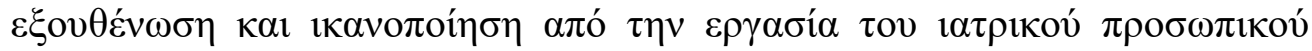

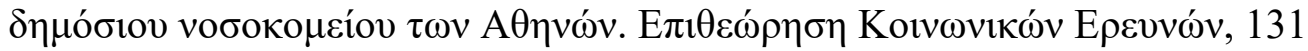
(A), 109-136.

[2] Antoniou, A.S., Davidson, M. J., \& Cooper, C.L. (2003). Occupational stress, job satisfaction and health state in male and female junior hospital doctors in Greece. Journal of Managerial Psychology, 18(6), 592-621.

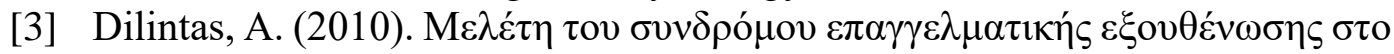

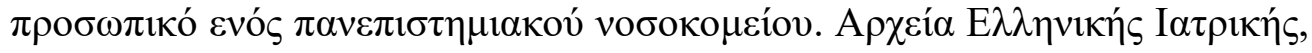
27(3), 498-508.

[4] Douvanas, A., Mpaliou, M., Pantelaki, A., Pousderki, P., Marvaki, C. (2011).

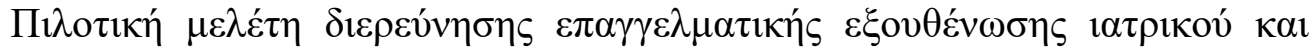

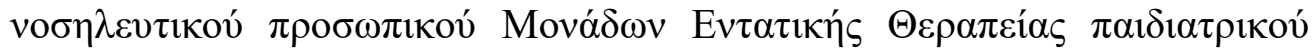

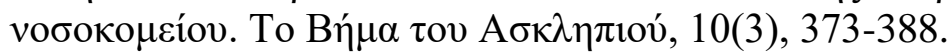

[5] Edelwich, J., \& Brodsky, A. (1980). Burnout: Stages of Disillusionment in Helping Professions. New York: Human Sciences Press.

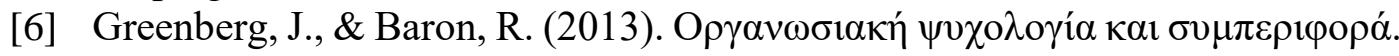
A $\theta \dot{v} v \alpha$ : Gutenberg.

[7] Gregoropoulou, M., Patsaki, A., Katsari, B., Sarafis, P., Mpampidis, P.,

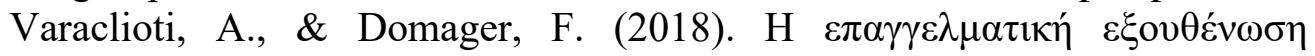

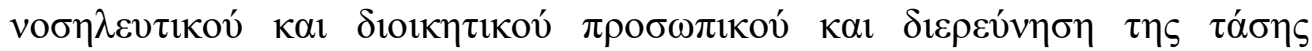

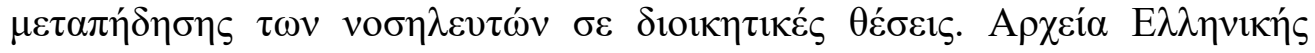
Іатрıки́s, 35(5), 633-641.

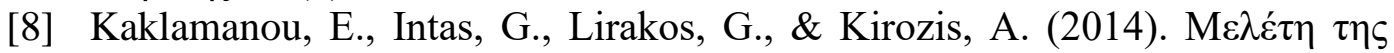

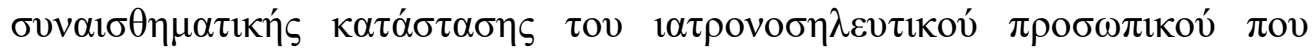

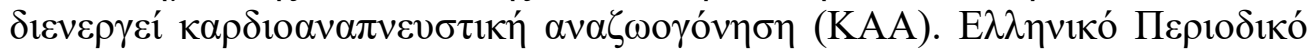

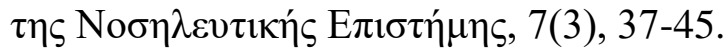

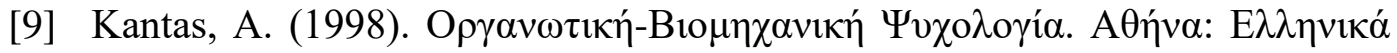

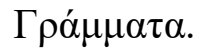

[10] Karaniadou, A., Anagnostopoulos, F., \& Telioni, M. (2006). $\Delta \eta \mu о \gamma \rho \alpha \varphi$ iкоí,

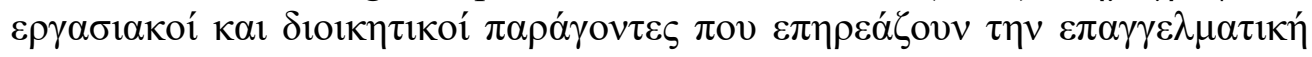

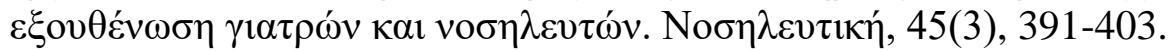

[11] Kiloudis, P., Georgiadis, M., Rekliti, M., Giaglis, G., Vosniak, G., Roupa, Z.

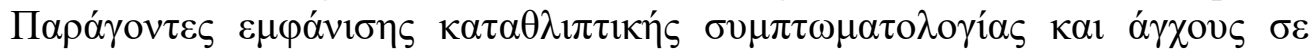

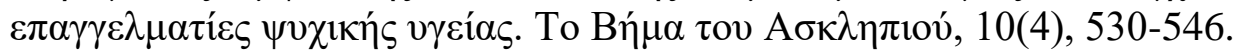

[12] Maslach, C., \& Jackson, S. (1986). Maslach Burnout Inventory. Palo Alto: Consulting Psychologists Press.

[13] Moustaka, E., Antoniadou, F., Malliarou, M., Zantzos, I., Kiriaki, K.,

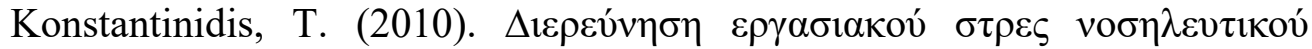

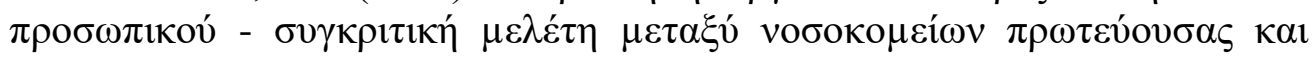

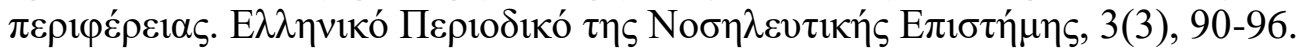


[14] Mpaltzi, E., Chari - Papaioannou, F., Polikandrioti, M., Gourni, M.,

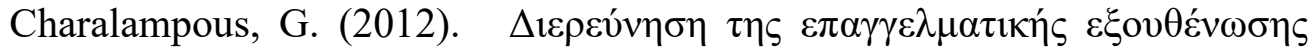

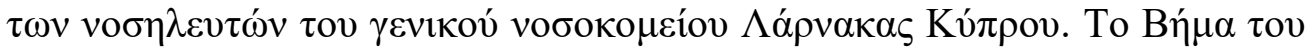

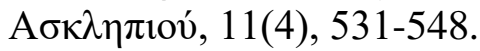

[15] Roupa, Z., Raftopoulos, V., Tzavelas, G., Sapountzi-Krepia, D., \& Kotrotsiou,

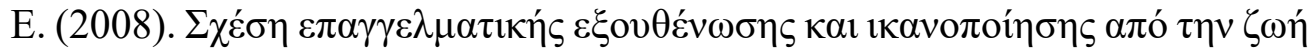

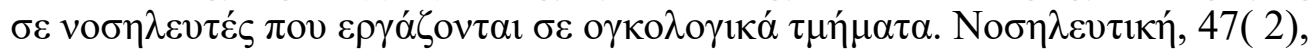
247-255.

[16] Tsaras, K., Daglas, A., Mitsi, D., Papathanasiou, I., Tzavella, F., Zyga, S., \& Fradelos, E. (2018). A cross-sectional study for the impact of coping strategies on mental health disorders among psychiatric nurses. Health Psychol Res., 6(1), 7466.

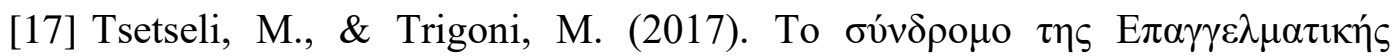

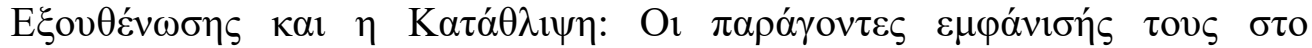

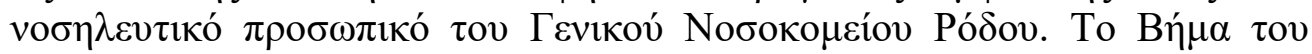

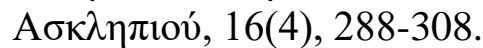

[18] Tsilias, D., Mpilali, A., Galanis, P., Mpakoula, C., Salemi, G., Giannelis, A.,

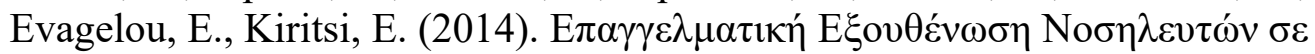

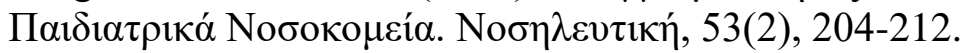

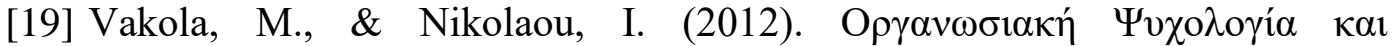

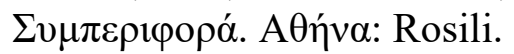

[20] Vlachou, E., Damigos, D., Lyrakos, G., Chanopoulos, K., Kosmidis, G., \& Karavis, M. (2016). The Relationship between Burnout Syndrome and Emotional Intelligence in Healthcare Professionals. Health Science Journal, 10(5). 